\title{
Meningkatkan Keaktifan Belajar Siswa Melalui Pendekatan Team Quiz Pada Materi Kegiatan Ekonomi di Kelas V MIN 1 Pekanbaru
}

\author{
Gustiani $^{*}$ Kusnadi ${ }^{* *}$ \\ *,** Program Studi Pendidikan Ekonomi Universitas Islam Negeri Sultan Syarif Kasim Riau, Pekanbaru \\ gustiani@gmail.com, kusnadi@gmail.com
}

\section{INFO ARTIKEL}

\section{Riwayat Artikel:}

Diterima: 12 Oktober 2018

Disetujui: 25 Juni 2019

\section{Kata kunci:}

Keaktifan Belajar Siswa

Pendekatan Team Quiz

Materi Kegiatan Ekonomi

\section{Alamat Korespondensi:}

Kusnadi,

Program Studi Pendidikan Ekonomi Universitas Islam Negeri Sultan Syarif Kasim Riau, Pekanbaru Email:kusnadi@gmail.com

\begin{abstract}
This study aims to determine the increase in student learning activeness through the Team Quiz approach on economic activity material in Class V MIN 1 Pekanbaru. Silbermen explained that this Team Quiz can increase students' sense of responsibility for what they learn by pleasing and not threatening or scaring them. From the application of this method, it is expected to be able to increase the learning activeness of V MIN 1 Pekanbaru students in social studies learning. Based on the results of the study, in the first cycle obtained an average of $58.5 \%$ with a high category because it is in the range of $56 \%-75 \%$. While in cycle II it increased by an average percentage of $75.7 \%$ with a high category because it was still in the range of $56 \%-75 \%$. This means that this research is said to be successful, because it has exceeded the established success indicators (70\%)..
\end{abstract}

Abstrak: Penelitian ini bertujuan untuk mengetahui peningkatan keaktifan belajar siswa melalui pendekatan Team Quiz pada materi kegiatan ekonomi di Kelas V MIN 1 Pekanbaru. Silbermen menjelaskan bahwa Team Quiz ini dapat meningkatkan rasa tanggung jawab siswa atas apa yang mereka pelajari dengan cara menyenangkan dan tidak mengancm atau tidak membuat mereka takut. Dari penerapan metode ini diharapakan dapat meningkatkan keaktifan belajar siswa kelas V MIN 1 Pekanbaru dalam pembelajaran IPS. Berdasarkan hasil penelitian, pada siklus I diperoleh rata-rata 58,5\% dengan kategori tinggi karena berada pada rentang 56\%-75\%. Sedangkan pada siklus II meningkat dengan rata-rata persentase sebesar $75,7 \%$ dengan kategori tinggi karena masih berada pada rentang 56\%-75\%. Artinya penelitian ini dikatakan berhasil, karena telah melebihi indikator keberhasilan yang ditetapkan (70\%).

\section{LATAR BELAKANG}

Zaini (2008) menjelaskan bahwa pembelajaran aktif adalah suatu pembelajaran mengajak peserta didik untuk belajar secara aktif. Ketika peserta didik belajar dengan aktif, berarti mereka yang mendominasi aktifitas pembelajaran. Dengan ini mereka secara aktif menggunakan otak, baik untuk menemukan ide pokok dari materi kuliah, memecahkan persoalan atau mengaplikasikan apa yang baru mereka pelajari ke dalam satu persoalan nyata. Dengan belajar aktif ini, peserta didik diajak untuk turut serta dalam semua proses pembelajaran, tidak hanya mental akan tetapi juga melibatkan fisik. Dengan cara ini biasanya peserta didik akan merasakan suasana yang lebih menyenangkan sehingga hasil belajar dapat dimaksimalkan.

Selanjutnya, belajar aktif itu sangat diperlukan oleh peserta didik untuk mendapatkan hasil belajar yang maksimum. Ketika peserta didik pasif, atau hanya menerima dari pengajar, ada kecendrungan untuk cepat melupakan apa yang telah diberikan. Oleh sebab itu, diperlukan perangkat tertentu untuk dapat mengikat informasi yang baru saja diterima dari dosen. Belajar aktif adalah salah satu cara untuk mengikat informasi yang baru kemudian menyimpannya dalam otak. Mengapa demikian? Karena salah satu faktor yang menyebabkan informasi cepat dilupakan adalah faktor kelemahan otak manusia itu sendiri. Belajar hanya mengandalkan indera pendengaran mempunyai beberapa kelemahan, padahal hasil belajar seharusnya disimpan sampai waktu yang lama. Kenyataan ini 
sesuai dengan kata-kata mutiara yang diberikan oleh seorang filosof kenamaan dari Cina, konfusius. Dia mengatakan : Apa yang saya dengan saya lupa, apa yang saya lihat saya ingat dan apa yang saya lakukan saya faham (Zaini, 2008). Berdasarkan penjelasan di atas, dapat dipahami bahwa dengan adanya aktifitas belajar yang baik maka siswa akan belajar lebih aktif dan pada akhirnya hasil belajar dapat dicapai secara maksimal. Untuk itu aktifitas sangat diperlukan dalam proses pembelajaran, terutama pada mata pelajaran Ilmu Pengetahuan Sosial (IPS) terutama pada materi kegiatan ekonomi.

Hal ini sangat sejalan yang dinyatakan oleh Oermar Hamalik bahwa penggunaan asas aktifitas besar nilainya bagi pengajaran para siswa, oleh karena ; 1) para siswa mencari pengalaman sendiri dan langsung mengalami sendiri, 2) berbuat sendiri akan mengembangkan seluruh aspek pribadi siswa secra integral, 3) memupuk kerjasama yang harmonis di kalangan siswa, 4) para siswa bekerja menurut minat dan kemampuan sendiri, 5) memupuk disiplin kelas secara wajar dan suasana belajar menjadi demokratis, 6) mempererat hubungan sekolah dan masyarakat, dan hubungan antara orang tua dengan guru, 7) pengajaran diselenggarakan secara realistis dan konkret sehinga mengembangkan pemahaman dan berpikir kritis serta menghindarkan verbalistis dan 8) pengajaran di sekolah menjadi hidup sebagaimana aktivitas dalam kehidupan di masyarakat (Hamalik, 2004).

Hamalik (2004) mengemukakan kemampuan-kemampuan yang selama ini harus dikuasai guru juga akan lebih dituntut aktualisasinya. misalnya kemampuannya dalam: 1) merencanakan pembelajaran dan merumuskan tujuan, 2) mengelola kegiatan individu, 3) menggunakan multi metode, dan memanfaatkan media, 4) berkomunikasi interaktif dengan baik, 5) keaktifan dan memberikan respons, 6) melibatkan siswa dalam aktivitas, 7) mengadakan penyesuaian dengan kondisi siswa, 8) melaksanakan dan mengelola pembelajaran, 9) menguasai materi pelajaran, 10) memperbaiki dan mengevaluasi pembelajaran, 11) memberikan bimbingan, berinteraksi dengan sejawat dan bertanggungjawab kepada konstituen serta, 12) mampu melaksanakan penelitian. Kelancaran proses seluruh kegiatan pendidikan terutama di sekolah, sepenuhnya berada dalam tanggung jawab para guru agar siswa menjadi aktif. Ia adalah seorang pemimpin yang harus mengatur, mengawasi dan mengelola seluruh kegiatan proses pembelajaran di sekolah yang menjadi lingkup tanggung jawabnya. Peran semua unsur sekolah, orang tua siswa dan masyarakat sangat penting dalam mendukung keberhasilan pencapaian tujuan pembelajaran, termasuk di dalamnya Ilmu Pendidikan Sosial.

Di MIN 1 Pekanbaru seharusnya dalam melaksanakan pembelajaran siswa semangat dalam mengikuti proses pembelajaran, memiliki respon yang bagus dalam proses pembelajaran, mendengarkan penjelasan guru dengan baik dan berinisiatif untuk bertanya serta mampu berpartisifasi aktif dalam proses pembelajaran. Berdasarkan hasil pengamatan peneliti, bahwa kenyataan yang terjadi di lapangan masih jauh dari harapan-harapan yang ada. Kegiatan belajar merupakan bahagian dari proses pendidikan bagi anak, dewasa ini semakin mengalami kemunduran. Belajar semakin dianggap sebagai suatu kegiatan yang membosankan dan tidak berkembang. Pada tiap sekolah, situasinya tidak jauh berbeda, anak-anak umumnya kurang memiliki kreativitas dan kurang aktif dalam belajar khususnya dalam belajar IPS. Guru mengajar dengan materi yang sama dari tahun ke tahun atau catatan yang sama, banyaknya materi hapalan, gaya mengajar tidak berubah, tanpa menggunakan media pengajaran, standar, formal dan baku.

Berdasarkan pengalaman selama peneliti bertugas di MIN 1 Pekanbaru, penulis menemukan gejala-gejala atau fenomena pada IPS khususnya pada materi kegiatan ekonomi sebagai berikut: 1) adanya sebagian siswa yang kurang semangat dalam mengikuti proses pembelajaran; 2) kurangnya respon siswa dalam proses pembelajaran, hal ini dapat dilihat ketika guru memberikan suatu permasalahan untuk diseslesaikan siswa banyak yang diam dan tidak memberikan jawaban apa-apa; 3) jika guru menerangkan materi kegiatan ekonomi siswa hanya mendengarkan tanpa berinisiatif untuk bertanya; dan 4) bila diminta untuk maju kedepan kelas melakukan sesuatu siswa kurang bersemangat. Berdasarkan gejala-gejala di atas, dapat dikatakan bahwa aktifitas belajar siswa dalam proses pembelajaran IPS cenderung rendah. Untuk itu, melalui penelitian ini penulis berusaha untuk memperbaiki aktifitas belajar siswa dalam proses pembelajaran. Salah satu usaha untuk memperbaiki proses pembelajaran tersebut adalah dengan menggunakan pendekatan Team Quiz.

Silbermen (2006) menjelaskan bahwa Team Quiz ini dapat meningkatkan rasa tanggung jawab siswa atas apa yang mereka pelajari dengan cara menyenangkan dan tidak mengancam atau tidak membuat mereka takut. Zaini (2008) menjelaskan bahwa pembelajaran aktif adalah suatu pembelajaran mengajak peserta didik untuk belajar secara aktif. Ketika peserta didik belajar dengan aktif, berarti mereka yang mendominasi aktifitas pembelajaran. Dengan ini mereka secara aktif menggunakan otak, baik untuk menemukan ide pokok dari materi kuliah, memecahkan persoalan atau mengaplikasikan apa yang baru mereka pelajari ke dalam satu persoalan nyata. Dengan belajar aktif ini, peserta didik diajak untuk turut serta dalam semua proses pembelajaran, tidak hanya mental akan tetapi juga melibatkan fisik. Dengan cara ini biasanya peserta didik akan merasakan suasana yang lebih menyenangkan sehingga hasil belajar dapat dimaksimalkan.

Pendekatan team quiz merupakan bagian dari PAIKEM, yaitu pembelajaran aktif, inovatif, kreatif, efektif dan menyenangkan. Dikatakan demikian karena pembelajaran yang dirancang hendaknya dapat mengaktifkan peserta didik, mengembangkan kreativitas yang pada akhirnya efektif, akan tetapi tetap menyenangkan bagi para peserta didik. Selanjutnya pendekatan team quiz sangat penting diterapkan dalam pembelajaran karena: 1) siswa terlibat 
dalam berbagai kegiatan yang mengembangkan pemahaman dan kemampuan mereka dengan penekanan pada belajar melalui berbuat; 2) guru menggunakan berbagai alat bantu dan cara membangkitkan semangat, termasuk menggunakan lingkungan sebagai sumber belajar untuk menjadikan pembelajaran menarik, menyenangkan, dan cocok bagi siswa; 3) guru mengatur kelas dengan memajang buku-buku dan bahan belajar yang lebih menarik dan menyediakan pokok baca; 4) guru menerapkan cara mengajar yang lebih kooperatif dan interaktif, termasuk cara belajar kelompok; dan 5) guru mendorong siswa untuk menemukan caranya sendiri dalam pemecahan suatu masalah, untuk mengungkapkan gagasannya, dan melibatkan siswa dalam menciptakan lingkungan sekolahnya.

Berdasarkan keunggulan Team Quiz di atas, peneliti tertarik ingin melakukan suatu penelitian tindakan sebagai upaya dalam melakukan perbaikan terhadap pembelajaran dengan judul "Upaya Meningkatkan Keaktifan Belajar Siswa Melalui Pendekatan Team Quiz Pada Materi Kegiatan Ekonomi di Kelas V MIN 1 Pekanbaru”

\section{METODE}

Bentuk penelitian ini adalah penelitian tindakan kelas (PTK). Penelitian tindakan kelas merupakan salah satu kegiatan untuk mengatasi masalah yang terdapat di dalam kelas. Penelitian tindakan kelas (PTK) adalah suatu kegiatan penelitian ilmiah yang dilakukan secara rasional dan sistematis terhadap berbagai tindakan yang dilakukan oleh guru (tenaga pendidik), kolaborasi (tim peneliti), sejak disusunnya suatu perencanaan sampai penilaian terhadap tindakan nyata didalam kelas yang berupa kegiatan belajar mengajar, untuk memperbaiki dan meningkatkan kondisi pembelajaran yang dilakukan (Iskandar, 2009). Adapun subjek dalam Penelitian ini adalah murid kelas $\mathrm{V}$ yang berjumlah 25 orang yang terdiri dari 12 orang laki-laki dan 13 orang perempuan. Sedangkan objek penelitian ini adalah Upaya Meningkatkan Keaktifan Belajar Siswa Melalui Pendekatan Team Quiz Pada Materi Kegiatan Ekonomi di Kelas V MIN 1 Pekanbaru. Penelitian ini terdiri dari 2 siklus. Adapun setiap siklus dilakukan dalam 2 kali pertemuan. Maksudnya guru membuat Rencana Pelaksanaan Pembelajaran sebanyak 2 x pertemuan. Hal ini dimaksudkan agar siswa dan guru dapat beradaptasi dengan metode pembelajaran yang diteliti. Sehingga hasil penelitian tindakan kelas dapat dimanfaatkan dalam proses belajar mengajar selanjutnya. Namun, apabila keaktifan belajar belum tercapai sesuai dengan tujuan yang dicapai. Dilakukan siklus berikutnya dengan 2 kali pertemuan. Jenis data yang diperoleh dalam penelitian ini yaitu : jenis data kualitatif dan data kuantitatif, yang terdiri dari: 1) aktivitas guru dalam pelaksanaan pembelajaran diperoleh melalui lembar observasi; dan 2) aktivitas siswa dalam pelaksanaan pembelajaran diperoleh melalui lembar; serta 3) keaktifan siswa dalam pelaksanaan pembelajaran diperoleh melalui lembar observasi. Setelah data terkumpul melalui observasi, data tersebut diolah dengan menggunakan rumus persentase (Sudjono, 2004).

\section{HASIL}

\section{Hasil Observasi Keaktifan Belajar Sebelum Tindakan}

Setelah dilakukan analisis terhadap keaktifan belajar siswa sebelum tindakan, diketahui bahwa keaktifan belajar siswa sebelum tindakan dalam pelajaran Ilmu Pengetahuan Sosial pada siklus I tindakan tergolong rendah dengan jumlah rata-rata 41.6 atau berada pada rentang persentase 40-55. Analisis sementara penulis rendahnya keaktifan siswa dalam belajar disebabkan karena metode atau strategi pembelajaran yang diterapkan oleh guru masih metodemetode lama, yang cenderung monoton, sehingga siswa cepat jenuh. Keaktifan belajar siswa sebelum diterapkan pendekatan Team Quiz dalam pelajaran Ilmu Pengetahuan Sosial siswa secara klasikal masih tergolong rendah dengan perolehan rata-rata persentase 41.6\%. Persentase ini berada pada interval 40-55\%, pada kategori rendah. Oleh sebab itu, peneliti sekaligus merangkap sebagai guru melakukan langkah-langkah untuk mengatasi masalah rendahnya keaktifan belajar siswa dalam pelajaran Ilmu Pengetahuan Sosial melalui pendekatan Team Quiz.

\section{Siklus 1}

Berdasarkan observasi aktifitas guru, dapat digambarkan bahwa secara keseluruhan aktivitas guru dalam penggunaan pendekatan Team Quiz pada siklus I pertemuan I dengan alternatif jawaban "Ya” dan "Tidak", maka diperoleh jawaban "Ya" 3 kali dengan persentase 33,3\%. Sedangkan alternatif "Tidak" sebanyak 6 kali dengan persentase sebesar $66,7 \%$. Dengan persentase tersebut (33,3\%) maka disimpulkan bahwa aktivitas guru pada siklus I pertemuan 1 tergolong sangat rendah. Sedangkan aktifitas siswa pada siklus I pertemuan 1 menunjukkan bahwa aktivitas siswa secara klasikal tergolong tinggi dengan persentase 56\%. Dengan berpedoman pada penilaian yang dikemukakan sebelumnya maka dapat disimpulkan bahwa aktivitas belajar siswa pada siklus I pertemuan 1 menunjukkan secara klasikal tergolong cukup tinggi karena berada pada rentanng persentase 56\% - 75\%. Selanjutnya, keaktifan belajar siswa pada siklus I Pertemuan I secara klasikal tergolong cukup tinggi dengan perolehan rata-rata persentase 55,2\%. Dengan berpedoman pada penilaian yang dikemukakan pada Bab III, maka dapat disimpulkan bahwa keaktifan belajar siswa pada siklus I Pertemuan I secara klasikal tergolong remdah, karena $55,2 \%$ berada pada interval 56\%-75\%.

Berdasarkan observasi aktifitas guru, secara keseluruhan aktivitas guru dalam penggunaan pendekatan Team Quiz pada siklus I pertemuan I dengan alternatif jawaban "Ya" dan "Tidak", maka diperoleh jawaban "Ya” 5 kali dengan 
persentase 55,6\%. Sedangkan alternatif "Tidak" sebanyak 4 kali dengan persentase sebesar 44,4\%. Dengan persentase tersebut $(55,6 \%)$ maka disimpulkan bahwa aktivitas guru pada siklus I pertemuan 2 masih tergolong rendah. Berdasarkan hasil observasi aktivitas siswa pada siklus I pertemuan 2 menunjukkan bahwa aktivitas siswa secara klasikal tergolong cukup tinggi dengan persentase 62,2\%. Dengan berpedoman pada penilaian yang dikemukakan sebelumnya maka dapat disimpulkan bahwa aktivitas belajar siswa pada siklus I pertemuan 2 menunjukkan bahwa aktivitas siswa secara klasikal masih tergolong tinggi karena berada pada rentanng persentase 56\% - 75\%. Keaktifan belajar siswa pada siklus I Pertemuan 2 secara klasikal tergolong tinggi dengan perolehan rata-rata persentase $61,9 \%$. Hal ini berpedoman pada penilaian yang dikemukakan pada Bab III, karena persentase 61,9 berada pada interval $56 \%-75 \%$.

Kemudian secara umum, selama melakukan tindakan sebanyak 2 kali pertemuan terdapat banyak sekali kekurangan-kekurangan yang dilakukan oleh guru dan siswa. Kekurangan-kekurangan tersebut di antaranya adalah sebagai berikut: 1) meminta kelompok A memberi pertanyaan kepada kelompok C, jika kelompok $\mathrm{C}$ tidak bisa menjawab, lemparkan kepada kelompok B; 2) melanjutkan pelajaran kedua, dan guru menunjuk kelompok B untuk menjadi kelompok penanya. Dan guru melakukan seperti proses untuk kelompok A; 3) melanjutkan pelajaran ketiga, dan kemudian guru menunjuk kelompok C sebagai penanya; 4) mengakhiri pelajaran dengan menyimpulkan tanya jawab dan menjelaskan sekiranya ada pemahaman siswa yang keliru. Mencermati kelemahan-kelemahan yang ditemukan pada siklus I, maka guru atau penelitin menyusun rencana yang akan dilakukan untuk memperbaiki tindakan antara lain: 1) mengatur waktu seefektif mungkin agar pelaksanaan pembelajaran berikutnya dapat berjalan dengan baik; 2) memantau dan memberikan bimbingan yang lebih merata kesemua kelompok sehingga siswa mengetahui apa yang harus dikerjakan dan lebih serius dalam belajar; 3) memberikan penjelasan betapa pentingnya kerjasama dalam kelompok sehingga dalam menyelesaikan suatu permasalahan siswa dapat lebih kreatif dan tidak hanya mengandalkan guru; dan 4) guru berusaha semaksimal mungkin untuk bisa memonitoring siswa dan memfasilitasi semua kegiatan siswa, baik secara individu maupun kelompok dengan cara bekerjasama dengan pengamat.

\section{Siklus 2}

Berdasarkan data observasi aktifitas guru, dapat dijelaskan bahwa secara keseluruhan aktivitas guru dalam penggunaan pendekatan Team Quiz pada siklus II pertemuan I dengan alternatif "Ya" dan "Tidak", maka diperoleh jawaban "Ya" 7 kali dengan persentase 77,8\%. Sedangkan alternatif "Tidak" sebanyak 2 kali dengan persentase sebesar 22,2\%. Dengan persentase tersebut (77,8\%) maka disimpulkan bahwa aktivitas guru pada siklus II pertemuan 1 tergolong tinggi. Sedangkan aktivitas guru pada siklus II pertemuan 2 telah terjadi peningkatan alternatif jawaban "Ya" menjadi 100\%. Berdasarkan data yang diperoleh, dapat digambarkan bahwa secara keseluruhan aktivitas guru dalam penggunaan pendekatan Team Quiz pada siklus II pertemuan 2 dengan alternatif jawaban "Ya” dan "Tidak", maka diperoleh jawaban "Ya" 9 kali dengan persentase 100\%, dan tidak tidak ada aktivitas yang tidak dilaksanakan oleh guru. Dengan persentase tersebut (100\%) maka disimpulkan bahwa aktivitas guru pada siklus II pertemuan 2 tergolong sangat tinggi. Berdasarkan hasil observasi aktivitas siswa pada siklus II pertemuan 1 menunjukkan bahwa aktivitas siswa secara klasikal tergolong tinggi dengan persentase 65,3\%. Dengan berpedoman pada penilaian yang dikemukakan sebelumnya maka dapat disimpulkan bahwa aktivitas siswa secara klasikal tergolong tinggi karena berada pada rentanng persentase 56\% - 75\%. Sedangkan pada siklus II pertemuan 2 aktivitas siswa meningkat menjadi 87,6\%. Berdasarkan hasil observasi aktivitas siswa pada siklus II pertemuan 2 menunjukkan bahwa aktivitas siswa secara klasikal tergolong cukup tinggi dengan persentase $87,6 \%$. Dengan berpedoman pada penilaian yang dikemukakan sebelumnya maka dapat disimpulkan bahwa aktivitas siswa secara klasikal tergolong sangat tinggi karena berada pada rentanng persentase $76 \%$ - 100\%. Keaktifan belajar siswa pada siklus II Pertemuan I secara klasikal tergolong tinggi dengan perolehan rata-rata persentase 65,6\%. Dengan berpedoman pada penilaian yang dikemukakan pada Bab III, maka dapat disimpulkan bahwa keaktifan belajar siswa pada siklus II Pertemuan I secara klasikal tergolong tinggi, karena 65,6\% berada pada interval 56\%-75\%. Sedangkan hasil observasi keaktifan belajar siswa pada siklus II pertemuan 2 mengalami pengkatan persentase sebesar $85,9 \%$.

Berdasarkan hasil penelitian yang dikemukakan sebelumnya, yakni pada siklus II, menunjukkan bahwa keaktifan belajar siswa telah mencapai 75,7\% secara klasikal. Tercapainya persentase ini disebabkan oleh adanya perbaikanperbaikan yang telah disusun sebelumnya. Dengan demikian, peneliti menyimpulkan untuk tidak melanjutkan penelitian pada siklus berikutnya. Karena persentase keaktivan siswa telah melebihi indikator keberhasilan yang ditetapkan (70\%).

\section{PEMBAHASAN}

Melalui pengamatan peneliti selama proses pembelajaran berlangsung, aktivitas guru dan siswa sangat tinggi. Siswa terlihat lebih bersemangat dalam belajar dan lebih partisipatif dalam proses pembelajaran. Dalam mengikuti setiap aktivitas pembelajaran, siswa berusaha memahami materi dengan cara bertanya dengan teman, bertanya pada guru, menyimak penjelasan teman yang menampilkan hasil diskusi, dan membaca buku tentang materi yang akan 
dipelajari. Hal ini juga terlihat dari kemajuan belajar siswa, dimana siswa lebih berani mengeluarkan pendapatnya dalam berdiskusi dan mampu menyelesaikan soal latihan yang ada pada lembar tugas.

Selama proses penelitian ada beberapa hal yang menjadi kendala dalam penelitian diantarany: pada awal pertemuan, banyak siswa yang belum terbiasa dengan langkah-langkah atau tahap yang dilakukan dalam proses pembelajaran dengan pendekatan Team Quiz. Pada tahap diskusi kelompok di pertemuan pertama dan kedua, masih ada siswa yang masih bekerja secara individu, tidak mau bertukar pendapat dengan anggota kelompok lainnya. Guru juga belum dapat menggunakan waktu sesuai dengan perencanaan. Untuk mengatasi hal tersebut guru memberikan penjelasan betapa pentingnya kerja sama dalam kelompok sehingga dalam menyelesaikan permasalahan siswa dapat lebih kreatif dan tidak hanya mengandalkan guru, guru meyakinkan siswa bahwa ia mempunyai kemampuan untuk melaksanakan tugas yang diberikan kepadanya. Guru juga lebih tegas dalam penggunaan waktu agar semua tahap yang telah direncanakan dapat terlaksana.

Permasalahan tersebut diperbaiki dan dilaksanakan dengan lebih baik pada pertemuan berikutnya sehingga pada akhirnya pelaksanaan pendekatan Team Quiz dapat memberikan kesempatan kepada siswa lain, bertanya kepada guru, menanggapi pertanyaan dan berargumentasi, dan meningkatkan aktivitas belajar dan rasa tanggung jawab siswa serta mengembangkan kemampuan berkomunikasi dengan siswa lain. Dari hasil observasi disimpulkan bahwa keaktifan belajar siswa pada materi Ilmu Pengetahuan Sosial dengan penerapan pendekatan Team Quiz mengalami peningkatan dibandingkan sebelum tindakan. Hal ini diketahui dari data awal hanya diperoleh $41,6 \%$ dengan kategori rendah. Setelah diterapkannya pendekatan Team Quiz, maka keaktivan siswa meningkat dengan rata-rata $58,5 \%$. Sedangkan pada siklus II tercapai rata-rata 75,7\% dengan kategori tinggi. Hasil rekapitulasi keaktivan siswa dari data awal, siklus I, dan siklus II juga dapat dilihat pada histogram di bawah ini.

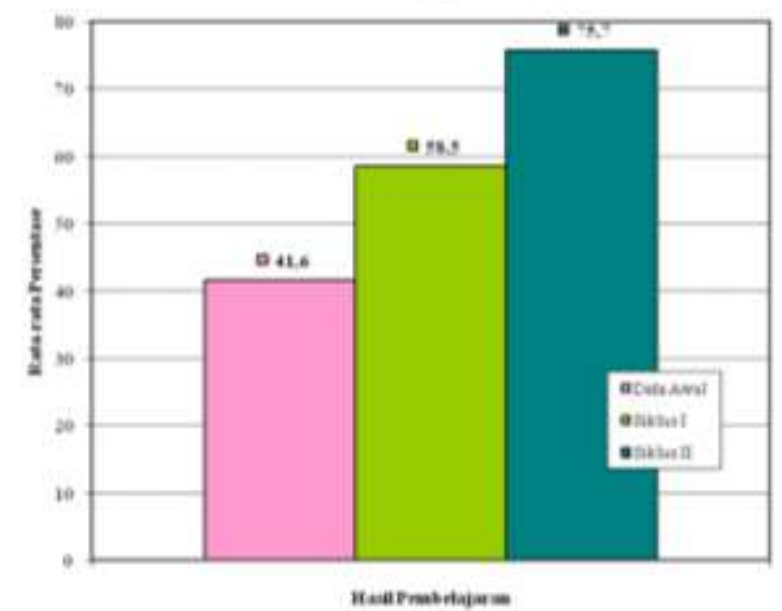

Gambar 1. Rekapitulasi Keaktifan Belajar Siswa Dari Data Awal, Siklus I dan Siklus II

\section{SIMPULAN DAN SARAN}

\section{Simpulan}

Berdasarkan hasil pembahasan dan analisis seperti disampaikan pada bab IV dapat disimpulkan bahwa melalui penerapan pendekatan Team Quiz, dapat meningkatkan keaktifan belajar pada pelajaran Ilmu Pengetahuan Sosial siswa V MIN Pekanbaru. Hal ini diketahui dari hasil observasi bahwa keaktifan belajar siswa dalam mengikuti pembelajaran Ilmu Pengetahuan Sosial melalui pendekatan Team Quiz mengalami peningkatan dibandingkan sebelum tindakan. Hal ini ditunjukkan dengan angka persentase akhir dengan rata-rata 75,7\% atau dengan kategori tinggi. Keberhasilan tersebut dapat tercapai karena penerapan pendekatan pembelajaran Team Quiz, aktivitas siswa menjadi lebih aktif yang berarti siswa cenderung positif dalam mengikuti proses pembelajaran yang diberikan oleh guru. Dengan demikian maka tingkat penerimaan siswa akan meningkat dan pada gilirannya dan secara tidak langsung dapat meningkatkan keaktifan belajar mereka.

\section{Saran}

Sesuai hasil dari kesimpulan dan pembahasan hasil penelitian di atas, di mana berkaitan dengan pendekatan pembelajaran Team Quiz yang telah dilaksanakan, maka peneliti mengajukan beberapa saran, yaitu: 1) agar penerapan Pendekatan Team Quiz tersebut dapat berjalan dengan baik, maka sebaiknya guru lebih sering menerapkannya dalam proses pembelajaran, khususnya pada pelajaran Ilmu Pengetahuan Sosial; 2) diharapkan dengan adanya penelitian ini dapat menjadi pertimbangan bagi guru dalam memilih strategi pembelajaran dalam meningkatan keaktifan belajar siswa; dan 3) guru perlu melakukan upaya-upaya guna mempertahankan keaktifan belajar siswa demi tercapainya hasil belajar yang optimal. 


\section{DAFTAR RUJUKAN}

Anas Sudjono, Pengantar Statistik Pendidikan, Jakarta: Raja Grafindo Persada, 2004

Hartono, dkk, PAIKEM Pembelajaran Aktif, Inovatif, Kreatif Efektif dan Menyengkan, Pekanbaru: Zanafa, 2008

Hartono, Strategi Pembelajaran, Pekanbaru: LSFK2P, 2006

Hisyam Zaini, Strategi Pembelajaran Aktif, Yogyakarta: CTSD, 2007

Oermar Hamalik, Proses Belajar Mengajar. Bandung. Rosda. 2004

Poerwadaminta, S.J.W. Kamus Besar Bahasa Indonesia. Jakarta: Balai Pustaka, 1985

Silbermen, Active Learning (101 Cara Belajar Siswa Aktif), Bandung: Nusa Media, 2006

Suharsimi Arikunto, Prosedur Penelitian Suatu Pendekatan Praktek, Jakarta: Rineka Cipta. 1998 